\title{
SOME CHEMICAL CONSIDERATIONS ON THE DISTRIBUTION OF IRON IN THE SEA
}

\author{
By L. H. N. Cooper, D.Sc., F.R.I.C.
}

Chemist at the Plymouth Laboratory

Three purely chemical topics which have arisen in the course of the investigation described in the preceding paper (Cooper, 1948) will be discussed; first, a theoretical treatment of the formation and stability of ferric phosphate in sea water; secondly, an explanation as to how 2:2'-dipyridyl may react with ferric iron at high dilutions in natural waters to give the red ferrous complex; and thirdly, a short account of an experiment which showed ferrifluoride to be unstable in sea water.

\section{Formation and Stability of Ferric Phosphate in Sea Water}

Two series of experiments in this laboratory by Harvey (1937) and by the writer (unpublished) on the precipitation of iron from sea water containing phosphate and hydroxyl ions ( $\mathrm{pH} 8 \cdot \mathrm{I})$ do not agree. Sometimes much of the phosphate is precipitated, sometimes none. Much closer control is necessary but it has not been clear what form this should take. The following theoretical examination, imperfect though it is, may help in the design of such control.

Pugh \& du Toit (1936) examined the ionic exchange or hydrolysis of ferric phosphate and silicate in relatively concentrated systems. Solutions of ferric chloride were titrated with solutions of phosphate or silicate containing varying amounts of sodium hydroxide. A ferric phosphate with a higher $\mathrm{PO}_{4} / \mathrm{Fe}_{2} \mathrm{O}_{3}$ mol-ratio than 0.7I could not be prepared since compounds richer in phosphate hydrolysed until this ratio was reached. There is an optimum value of $\mathrm{pH}$ above which the ferric phosphate hydrolyses further with increasing hydroxyl-ion concentration. The same is true of ferric silicate. At $\mathrm{pH} 8.0$ and above, in presence of hydroxyl, silicate and phosphate in solution, ferric hydroxide would be the stable solid phase. The isoelectric point of ferric hydroxide prepared from its chloride is said to be $\mathrm{pH} 7 \cdot \mathrm{I}$ so that at $\mathrm{pH} 8$. I ferric hydroxide should be regarded rather as the very sparingly soluble ferrous acid, $\mathrm{H}_{3} \mathrm{FeO}_{3}$, which may be expected to dissociate

$$
\mathrm{H}_{3} \mathrm{FeO}_{3} \rightleftharpoons \mathrm{H}^{+}+\mathrm{H}_{2} \mathrm{FeO}_{3}^{\prime} \text {. }
$$

Since $\mathrm{FeOH}^{++}$is the dominant ferric cation at the isoelectric point, for electroneutrality of the micelle, the concentration of its anion, $\mathrm{H}_{2} \mathrm{FeO}_{3}^{\prime}$, should be twice that of its cation, $\mathrm{FeOH}^{++}$. This (Cooper, $1937 b$, equation $\mathrm{I} 2$ ) will be about $10^{-12.54}$ at $18^{\circ} \mathrm{C}$. The solubility product of ferrous acid, $\left(\mathrm{H}^{+}\right)\left(\mathrm{H}_{2} \mathrm{FeO}_{3}^{\prime}\right)$ will therefore be of the order

$$
1 \mathrm{O}^{-7 \cdot 1} \times \mathrm{I} 2 \times 1 \mathrm{IO}^{-12 \cdot 54}=\mathrm{IO}^{-19 \cdot 3} \text {. }
$$


At $\mathrm{pH}$ 8. I the molar concentration of the ferrite ion would be about $10^{-11.2}$ or $0.006 \mu \mathrm{g}$.-atom $/ \mathrm{m}^{3}$. This figure cannot be very accurate since the isoelectric point of ferric hydroxide sols depends greatly upon the method of preparation.

Revut (1936) also states that on standing ferric phosphate sols slowly hydrolyse. The complexes may vary much in structure and calcium phosphate may be included (Kheifetz, 1936).

In the sea ferric hydroxide and phosphate will almost always be colloidal, conceivably but very rarely micro-crystalline and never macro-crystalline. In an azoic world, given sufficient time, thermodynamic equilibrium would no doubt in the end be reached, whereas in temperate surface waters of the sea, the speed of the life cycle is likely never to allow equilibrium conditions to be even remotely approached. Equilibrium values for ferric hydroxide have been discussed (Cooper, $1937 b)$ and at $p \mathrm{OH} 6.5\left(\mathrm{pH} 8\right.$ at $10^{\circ} \mathrm{C}$.) (Cooper 1937a) we should expect IO $^{-10 \cdot 9} \mu \mathrm{g}$.-atom $/ \mathrm{m}^{3} \mathrm{Fe}^{+++}$, IO ${ }^{-5 \cdot 3} \mu \mathrm{g}$.atom $/ \mathrm{m}^{3}{ }^{3} \mathrm{FeOH}{ }^{++}$and possibly $\mathrm{IO}^{-3} \mu$ g.-atom $/ \mathrm{m}^{3} \mathrm{H}_{2} \mathrm{FeO}_{3}^{\prime}$.

The amount of undissociated phosphoric acid, $\mathrm{H}_{3} \mathrm{PO}_{4}$, present in sea water must be minute (Nims, I934). Phosphate occurs mostly as the ions, $\mathrm{H}_{2} \mathrm{PO}_{4}^{\prime}$ and $\mathrm{HPO}_{4}^{\prime \prime}$. The second dissociation constant in terms of activities at infinite dilution has been most carefully determined by Nims (1933):

$$
K_{2}=\frac{a_{\mathrm{H}} a_{\mathrm{HPO}_{4}}}{a_{\mathrm{H}_{2} \mathrm{PO}_{4}}}=5.98 \times 10^{-8} \text { at } \mathrm{I}^{\circ} \mathrm{C} .
$$

At finite concentrations of solute, activity coefficients have to be introduced. Extrapolation from Nims' experimental upper limit of ionic strength, 0.15 , to the ionic strength of sea water, 0.7 , would involve laborious computations which the problem does not at present justify. Nevertheless, to give shape to the problem, the concentration of the tribasic ion, $\mathrm{PO}_{4}^{\prime \prime \prime}$ will be calculated at $\mathrm{pH} 8.0$ and 8.3 in a solution 'at infinite dilution', assuming that activity coefficients are all unity and that activities may be equated to molarities, written within parentheses. Since the concentrations of $\mathrm{H}_{3} \mathrm{PO}_{4}$ and $\mathrm{PO}_{4}^{\prime \prime \prime}$ are negligible compared with $\mathrm{H}_{2} \mathrm{PO}_{4}^{\prime}$ and $\mathrm{HPO}_{4}^{\prime \prime}$, the total concentration, of dissolved inorganic phosphate, $\Sigma P$ may be written

$$
\begin{aligned}
\Sigma P & =\left(\mathrm{H}_{2} \mathrm{PO}_{4}^{\prime}\right)+\left(\mathrm{HPO}_{4}^{\prime \prime}\right)=\frac{\left(\mathrm{H}^{+}\right)\left(\mathrm{HPO}_{4}^{\prime \prime}\right)}{K_{2}}+\left(\mathrm{HPO}_{4}^{\prime \prime}\right) \\
& =\left[\mathrm{I}+\frac{\left(\mathrm{H}^{+}\right)}{K_{2}}\right]\left(\mathrm{HPO}_{4}^{\prime \prime}\right) .
\end{aligned}
$$

For the third dissociation constant,

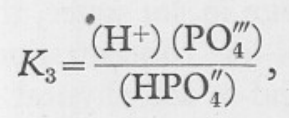


the literature values are divergent, Abbott \& Bray (1909) giving $3.6 \times 10^{-13}$ and Blanc (1920) $2 \times 10^{-12}$. A round figure of $10^{-12}$ will be assumed. Combining equations (2) and (3), we have:

$$
\left(\mathrm{PO}_{4}^{\prime \prime \prime}\right)=\frac{K_{2} K_{3}}{\left(\mathrm{H}^{+}\right)\left[K_{2}+\left(\mathrm{H}^{+}\right)\right]} \Sigma P=Q \Sigma P .
$$

$$
\begin{array}{cl}
\text { At } \mathrm{pH} 8.0, & Q=0.86 \times \mathrm{I0}^{-4}, \\
\text { and at } \mathrm{pH} \mathrm{8.3,} & Q=\mathrm{I} .84 \times \mathrm{I0}^{-4} .
\end{array}
$$

That is, if the alkalinity of sea water be raised from $\mathrm{pH} 8.0$ to $\mathrm{pH} 8.3$, the amount of tribasic ion 'at infinite dilution' would be doubled. In sea water the apparent dissociation constants will certainly differ markedly from those quoted, but the relative values of $Q$ will be much less in error.

Now let us consider the partition of iron between hydroxide and phosphate in sea water. Sea water is sufficiently well buffered for the hydroxyl-ion concentration to be considered constant. By contrast the total concentration of phosphate ions, $\Sigma P$, is very low and not much greater than the amount of particulate ferric phosphate inferred from analysis (Cooper, I948).

Let us assume that the solubility product of ferric phosphate,

$$
K_{\mathrm{FePO}_{4}}=\left(\mathrm{Fe}^{+++}\right)\left(\mathrm{PO}_{4}^{\prime \prime \prime}\right)=10^{-31 \cdot 5} .
$$

The equilibrium concentrations of ferric ion (Cooper, 1937b) would be $10^{-19 \cdot 9}$ at $\mathrm{pH} 8 \cdot 0$ and $10^{-21 \cdot 3}$ at $\mathrm{pH} 8 \cdot 3$.

By combining equations (4) and (5):

$$
\left(\mathrm{Fe}^{+++}\right) Q \Sigma P=10^{-31 \cdot 5} \text {, }
$$

so that at $\mathrm{pH} 8 \cdot 0, \Sigma P=34$ and at $\mathrm{pH} 8 \cdot 3, \Sigma P=\mathrm{I}$ IO $\mu$ g.-atom $/ \mathrm{m} .^{3}$.

This theoretical approach confirms the experimental finding of Pugh \& du Toit (above) in relatively very concentrated solution that the hydrolysis of ferric phosphate becomes greater the more alkaline the water. The conditions least favourable to the stability of ferric phosphate must therefore arise in the upper layers of the sea, during active plant growth. The formation and stability of ferric phosphate is likely to be most favoured under the more acid conditions found in the gut of many animals. Ferric phosphate is likely therefore to be introduced into sea water in faeces. It should be stressed that only the relative and not the absolute magnitudes of these calculations have meaning since the solubility product of ferric phosphate, $\mathrm{IO}^{-31 \cdot 5}$, was arbitrarily selected to give an answer within the realm of experience.

Doubt as to the correctness of these deductions springs less from the rather arbitrary nature of the calculation than from our complete ignorance as to how rapidly equilibrium conditions are attained. In all experimental work involving ferric phosphate in sea water, the need is indicated for very accurate control of hydroxyl-ion concentration (strictly activity) and for attention to the time factor and to the physical condition of the precipitated 
phase. The topic merits study not only from a biological but from a geochemical point of view. The equilibrium between ferric, hydroxyl and phosphate ions would seem to be precariously balanced and not always rapidly attained. It is likely to be strongly displaced by hydrostatic pressure which will affect the co-precipitation of iron and phosphate in deep-water deposits.

\section{Ferrous Iron IN THE SEA AND IN LAKES}

2:2'-Dipyridyl is now often used for characterizing ferrous as opposed to ferric iron at high dilutions in lake water (e.g. cf. Mortimer, 194I). Determinations made in the English Channel by the writer in 1933-34 (Cooper, I935, p. 422) and attributed to ferrous iron now appear to be nothing of the sort. An explanation is due. In the earlier work $100 \mathrm{ml}$. samples of sea water were treated with two drops of $4 \mathrm{~N}-\mathrm{HCl}$ and I ml. I \% dipyridyl in $0.2 \mathrm{~N}-\mathrm{HCl}$. Harvey (1937) has shown, and the writer has confirmed, that at high dilutions ferric iron will give rise to the red ferrous-tris-dipyridyl complex.

In sea water particulate and colloidal ferric hydroxide, phosphate and the like will approach an equilibrium with $\mathrm{Fe}^{+++}$and $\mathrm{FeOH}^{++}$whose concentration at the analytical $\mathrm{pH}$ of about 4.5 will not exceed about $50 \mu \mathrm{g}$.-atom $/ \mathrm{m} .^{3}$ :

$$
\begin{gathered}
\mathrm{Fe}(\mathrm{OH})_{3} \rightleftharpoons \mathrm{FeOH}^{++}+2 \mathrm{OH}^{\prime} \rightleftharpoons \mathrm{Fe}^{+++}+3 \mathrm{OH}^{\prime}, \\
\mathrm{FePO}_{4}+2 \mathrm{H}_{2} \mathrm{O} \rightleftharpoons \mathrm{Fe}^{+++}+\mathrm{H}_{2} \mathrm{PO}_{4}^{\prime}+2 \mathrm{OH}^{\prime} .
\end{gathered}
$$

These ferric ions will seek an equilibrium with ferrous ions which will be governed by the poise and $\mathrm{pH}$ of the system

$$
\begin{gathered}
\mathrm{Fe}^{+++}+\mathrm{e} \rightleftharpoons \mathrm{Fe}^{++}, \\
\mathrm{FeOH}^{++}+\mathrm{H}^{+}+\mathrm{e} \rightleftharpoons \mathrm{Fe}^{++}+\mathrm{H}_{2} \mathrm{O} .
\end{gathered}
$$

When undissociated dipyridyl (dipy) is present the ferrous ions will be rapidly removed.

$$
\mathrm{Fe}^{++}+3 \text { dipy } \rightleftharpoons \mathrm{Fe}(\text { dipy })_{3}^{++} .
$$

Reactions (I) to (4) will then proceed to restore the ferrous-ion concentration, providing that the necessary reducing electron can be found. If the oxygen electrode system, considered as a thermodynamically reversible system, be examined as the source of the electron:

$$
\mathrm{O}_{2}+2 \mathrm{H}_{2} \mathrm{O}+4 \mathrm{e} \rightleftharpoons 4 \mathrm{OH}^{\prime},
$$

we find that reduction of $200 \mu \mathrm{g}$.-atom $/ \mathrm{m}^{3}$ of ferric ion to ferrous ion would result in the oxidation of hydroxyl ion to $0.006 \mathrm{ml}$./1. dissolved oxygen. The change of poise of the system would be negligible as would the change in $p \mathrm{OH}$ or $\mathrm{pH}$ of even a weakly buffered water.

The reaction may also be formulated as proceeding through the weakly blue ferric-dipyridyl complex:

$$
\begin{aligned}
& \mathrm{Fe}^{+++}+3 \text { dipy } \rightleftharpoons \mathrm{Fe}(\text { dipy })_{3}^{+++}, \\
& \mathrm{Fe} \text { (dipy) }{ }_{3}^{+++}+\mathrm{e} \rightleftharpoons \mathrm{Fe}(\text { dipy })_{3}^{++} .
\end{aligned}
$$


The redox potential of this last reaction exceeds unity.

The source of the reducing electron should not be ascribed solely to the hydroxyl ion-oxygen system which, in fact, is not thermodynamically reversible but rather to the poising system of the water considered as a whole. The point of the argument is to show that in presence of a powerful combining reagent for ferrous ion such as $2: 2^{\prime}$-dipyridyl, ferric iron in a natural water at high dilution may seem to combine directly to give the ferrous-dipyridyl complex without needing the presence of a definite reducing agent in the usual macrochemical sense of the phrase. Thus the results in I933 and 1934 reported as ferrous iron certainly included some ferric iron as well.

\section{FERRIFLUORIDE IN SEA WATER}

It was earlier suggested (Thompson, Bremner \& Jamieson, I932; Cooper, 1935) that ferrifluoride may play a part in the iron cycle in the sea. An experiment made in May I 936 now shows this to be unlikely.

A well-washed, freshly prepared precipitate of ferric hydroxide was redissolved by treatment with excess hydrofluoric acid in a platinum dish. Addition of an equivalent solution of sodium carbonate gave a white precipitate of sodium ferrifluoride which was well washed by decantation to remove excess hydrofluoric acid. A few crystals of the moist precipitate on a loop of platinum wire were added to $250 \mathrm{ml}$. of sea water. The suspension slowly became yellow and finally ferric hydroxide separated. This experiment was repeated several times and indicates that, due to one of the reactions:

or

$$
\begin{aligned}
& \mathrm{FeF}_{6}^{\prime \prime \prime}+{ }_{3} \mathrm{H}_{2} \mathrm{O} \rightarrow \mathrm{Fe}(\mathrm{OH})_{3}+{ }_{3} \mathrm{HF}+{ }_{3} \mathrm{~F}^{\prime} \\
& \mathrm{FeF}_{6}^{\prime \prime \prime}+\mathrm{Al}^{+++}+{ }_{3} \mathrm{H}_{2} \mathrm{O} \rightarrow \mathrm{AlF}_{6}^{\prime \prime \prime}+\mathrm{Fe}(\mathrm{OH})_{3}+{ }_{3} \mathrm{H}^{+}
\end{aligned}
$$

ferrifluoride in sea water is unstable and plays no part in the iron economy of the sea.

\section{SUMMARY}

A theoretical study of the behaviour of ferric phosphate in sea water has been made with existing data. The conditions least favourable for the continued existence of ferric phosphate should occur in the upper layers of the sea during active plant growth. The formation and stability of ferric phosphate is likely to be most favoured under the more acid conditions found in the gut of many animals. Ferric phosphate is likely to be introduced into sea water in animal faeces. Experimental confirmation of this deduction is essential.

In all experimental work involving ferric phosphate in sea water, the need is indicated for very accurate control of hydroxyl-ion activity and probably pressure, and for attention to the time factor and to the physical condition of the precipitated phase. The topic is of geochemical as well as of biological interest. 
Dipyridyl is a reagent for ferrous iron. Reasons are set out why in sea and lake water at high dilutions it may also determine ferric iron without presence of an added reducing agent.

Evidence is presented that ferrifluoride plays no part in the iron cycle in he sea.

\section{ADDENDUM}

The Editor has shown me the proofs of a contribution to this Volume (pp. 360-79) by S. M. Marshall \& A. P. Orr (1948) on the effect of different plant nutrients upon the phytoplankton in Loch Craiglin. The deepest water (4-5 m.) was frequently oxygen-free, contained sulphide, and much resembled the freshwater studied by Mortimer (I94I) in Esthwaite Water (English Lake District). Such a stratification is likely to lead to the following distribution of iron and phosphate.

Oxygenated upper layers. Any iron present is likely to be largely colloidal or particulate ferric hydroxide which may or may not combine with phosphate to give particulate ferric phosphate. The balance of evidence has suggested that normal sea water may be too alkaline for this to happen. In Loch Craiglin the $\mathrm{pH}$ of surface water may even rise to over 9 .

Sulphide containing bottom water. In distilled water precipitated ferrous sulphide has a solubility of $70 \mathrm{mg} .-\mathrm{mol} / \mathrm{m}^{3}$ (Weigel, cit. Seidell, I920, p. 345). Its solubility in sea water is likely to have the same order of magnitude. Consequently, any amount of iron likely to be present in the foul bottom water of Loch Craiglin could be retained in solution as dissolved ferrous sulphide. The flagellate, Euglena proxima, was present mostly in or near the boundary between the two layers.

On I August I944 the loch had been fertilized with large quantities of superphosphate and sodium nitrate, most of which had been removed from the water by 7 August (Orr, 1947). Dissolved oxygen at $2 \mathrm{~m}$. had risen to $292 \%$ 'saturated' and the $\mathrm{pH}$ to $9 \cdot 82$. On samples taken on 9 August $\mathrm{Mr} \mathrm{H}$. Barnes made some iron analyses by the method used at Plymouth and in the oxygen-rich, very alkaline water at $\mathrm{O}, \mathrm{I}$ and $2 \mathrm{~m}$. was able to detect no iron. By contrast in the sulphide-containing water at $3 \mathrm{~m}$. about $0.36 \mathrm{mg}$.-atom $/ \mathrm{m}^{3}$ ferrous iron was found. The criticism, made above, as to the soundness of analyses for ferrous iron by this method are not valid for reducing waters such as that at $3 \mathrm{~m}$.

Iron, when once it has been immobilized in the bottom in any insoluble form, may be returned to the water physically by turbulence, by the agency of certain classes of animals, or by both together. Bacteria alone cannot bring it about under aerobic conditions. The important part played by faecal pellets in the bottom muds of the Clyde Sea area has been well shown by Moore (193I). The writer is being led more and more towards the view that detritus and suspension feeding animals hold a key position in the return of iron into 
circulation in a form usable by plants. It is surmised that these, either by triturating their food or by dissolving it in acid digestive juices, disperse iron surplus to their needs in their faeces and give it a measure of 'protection' by embedding it in organic colloids. After excretion into the overlying water, bacterial breakdown would further disperse this protected iron into a form usable by plants. This is a development of the argument already put forward by Harvey (I945, p. I37) as to the part played by zooplankton in the upper layers of the sea.

Though the minimal requirements of diatoms for iron are much less than those for phosphorus (Harvey, I937), some iron in a usable form is essential. It would now seem likely that the planktonic plants over the continental shelf require a proper balance of animals, both planktonic and bottom dwelling, to maintain their supply of iron in such a usable form. If therefore after addition of phosphatic and nitrogenous fertilizers, the plant population should become so great as to exclude a balanced growth of animals then the circulation of iron in a usable form would cease completely. Unlike phosphorus and nitrogen, bacterial decay alone would be unable to redress the balance. Subsequent addition of further phosphate and combined nitrogen to an enclosed body of water would then cause little further production of phytoplankton. Something of this sort may have happened on occasion in Loch Craiglin though it is not possible to separate the effects due to possible lack of usable iron from those due to high $\mathrm{pH}$ and disturbance of the carbon dioxide-bicarbonate system.

I am much indebted to Dr A. P. Orr for allowing me to see the typescript of his paper which is to appear in the Proceedings of the Royal Society of Edinburgh, for a criticism of this addendum and for a statement of his views. It is only fair to add that the Millport work was carried out during the war years concurrently with other work of higher priority. Many factors, including those discussed here, were well appreciated but in the very limited time available could not be examined. It is surprising indeed how much valuable data he and Dr Marshall were able to collect.

\section{REFERENCES}

Аввотt \& Bray, I909. Fourn. Amer. Chem. Soc., Vol. 18, p. 729; cit. Int. Crit. Tables, Vol. 7, p. 24I.

Blanc, I920. Fourn. chim. phys., Vol. I8, p. 28; cit. Int. Crit. Tables, Vol. 7, p. 24I. Cooper, L. H. N., I935. Iron in the sea and in marine plankton. Proc. Roy. Soc., B, Vol. II8, pp. 4I9-38.

- I937a. Oxidation-reduction potential in sea water. Fourn. Mar. Biol. Assoc., Vol. 22, pp. 167-76.

- I $937 b$. Some conditions governing the solubility of iron. Proc. Roy. Soc., B, Vol. I24, pp. 299-307.

I948. The distribution of iron in the waters of the western English Channel.

fourn. Mar. Biol. Assoc., Vol. 27, pp. 279-3I3. 
Harvey, H. W., I937. The supply of iron to diatoms. Fourn. Mar. Biol. Assoc., Vol. 22, pp. 203-I9.

- 1945. Recent advances in the chemistry and biology of sea-water. Cambridge University Press.

KhEIFETZ, D., I936. Composition and properties of phosphates of iron obtained under different conditions of precipitation. Chemisation of Socialistic Agr. (U.S.S.R.), No. 5, pp. 3-16; Chem. Abs., 1937, Vol. 31, col. I7I7.

MARshall, S. M. \& ORR, A. P., I948. Further experiments on the fertilization of a sea loch (Loch Craiglin). The effect of different plant nutrients on the phytoplankton. Fourn. Mar. Biol. Assoc., Vol. 27, pp. 360-79.

Moore, H. B., I93I. The muds of the Clyde Sea Area. III. Chemical and physical conditions; rate and nature of sedimentation; and fauna. fourn. Mar. Biol. Assoc., Vol. I7, pp. 325-58.

Mortimer, C. H., I94I. The exchange of dissolved substances between mud and water in lakes. Fourn. Ecol., Vol. 29, pp. 280-329; Vol. 30, pp. I47-20I.

Nims, L. F., I933. The second dissociation constant of phosphoric acid from $20^{\circ}$ to $50^{\circ}$. Fourn. Amer. Chem. Soc., Vol. 55, pp. I946-51.

1934. The first dissociation constant of phosphoric acid from $0^{\circ}$ to $50^{\circ}$. Fourn. Amer. Chem. Soc., Vol. 56, pp. IIIo-I2.

ORR, A. P., I947. An experiment in marine fish cultivation: II. Some physical and chemical conditions in a fertilized sea-loch (Loch Craiglin, Argyll). Proc. Roy. Soc. Edin., Vol. 63, pp. 3-20.

Pugh, A. J. \& DU ToIT, M. S., I936. The composition and ionic exchange of ferric silicates and phosphates. Soil Science, Vol. 4I, pp. 4I7-3I.

Revut, I. B., I936. The structure formation of iron phosphate sols. Fourn. Phys. Chem. (U.S.S.R.), Vol. 8, p. 791; Chem. Abs., I937, Vol. 31, col. I677.

Thompson, T. G., Bremner, R. W. \& Jamieson, I. M., I932. Ind.' Eng. Chem. (Anal.), Vol. 4, p. 288.

WeIgel, O., cit. SEIDELl, A., I920. Solubilities of inorganic and organic substances. and ed. Crosby Lockwood. 